BLS 33, No 1 2007. DOI: http://dx.doi.org/10.3765/bls.v33i1.3516

(published by the Berkeley Linguistics Society and the Linguistic Society of America)

\title{
Multiple Exponence of Derivational Morphology in Rarámuri (Tarahumara)
}

\author{
GABRIELA CABALLERO \\ University of California, Berkeley
}

\section{Background}

Theories of structural complexity and blocking (Anderson 1992, Andrews 1990) are challenged by the existence of Multiple Exponence (ME), a one-to-many mapping between a (morphological) category and its formal expression (Matthews 1972). Cases of ME, however, are well attested (e.g. agreement in Potawatomi (Anderson 1992), negation in Luganda (Peterson 1994), negation and agreement in Limbu (van Driem 1997)), and have been argued to support realizational theories of morphology and syntax. In these theories, morphosyntactic features are transferred and realized morphologically in several ways in the language (Matthews 1972, Stump 2001, Sells 2004); this entails that ME might be exhibited by inflectional categories, but not by categories that do not involve transfer of morphosyntactic features, such as argument structure changing operations.

Given the recursivity property of derivational morphology (Booij 2000), a derivational process may apply to a stem previously derived through the same process. In Rarámuri (Tarahumara), a causative stem may be causativized a second time, adding a second causer argument, as shown in (1b): ${ }^{1}$

\footnotetext{
* I would like to thank Sebastian Fuentes, Bertha Fuentes, Luz Elena León, Rosa Fuentes, Santos Fuentes, Giltro Fuentes Palma, Javier Holguín and Alicia Holguín for their patience in teaching me their language. I would also like to thank Andrew Garrett, Larry Hyman, Sharon Inkelas, Johanna Nichols, Andrew Spencer and the audiences of the Linguistic Association of Great Britain meeting in Newcastle and BLS 33 for their comments and suggestions. I would like to extend a special thanks to Teresa McFarland for extensive discussion of the material and analysis presented here. All errors are my responsibility. Work presented here is part of ongoing research on Choguita Rarámuri funded by the Hans Rausing Endangered Languages Project at SOAS, UCMEXUS, and the Survey of California and Other Indian Languages (UC Berkeley).

1 Abbreviations: A - Accusative; APPL - Applicative; CAUS - Causative; CAUS.IND - Indirect Causative; COP - Copula; COMP - Complementizer; DEM - Demonstrative; DESID - Desiderative; DUB - Dubitative; EV - Evidential; FUT.SG - Future sg; FuT.PL - Future Pl; FuT.PASS - Future Passive; HAB.PASS - Habitual Passive; INCH - Inchoative; INT - Intensive; MOT - Associated
} 


\section{Gabriela Caballero}

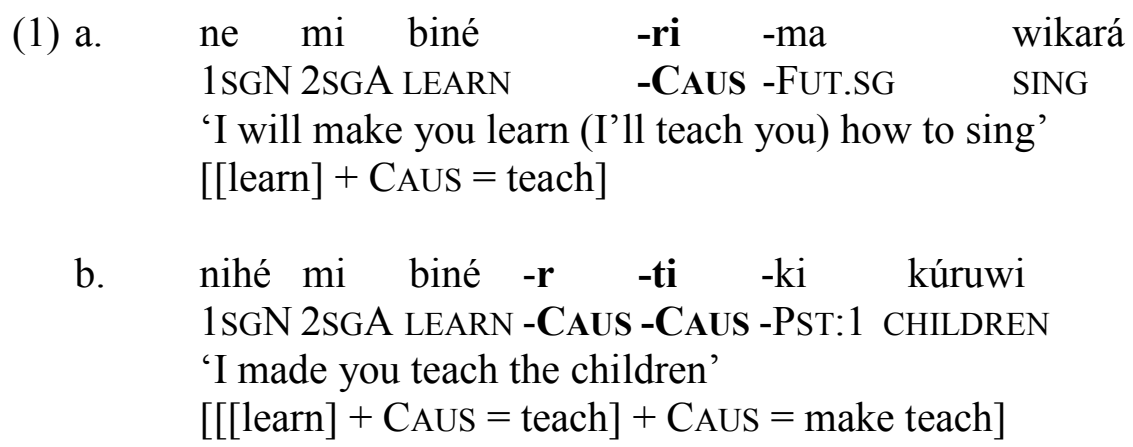

However, Rarámuri also displays multiple formal instances of the same derivational process with no parallel semantic recursivity, as shown in (2).

$$
\begin{aligned}
& \text { nihé mi rikú } \quad-r \quad \text {-ti } \quad \text {-ma } \\
& \text { 1SGN 2SGA GET.DRUNK -CAUS -CAUS -FUT.SG } \\
& \text { 'I will make you get drunk' (*'I will make you make her drunk') }{ }^{2}
\end{aligned}
$$

The example in (2) constitutes ME, since a single morphological category (one causer argument) is formally introduced by two exponents (two causative allomorphs).

This paper makes an empirical contribution by introducing several patterns of ME in Rarámuri, which crucially involve derivational information. ${ }^{3}$ This paper also shows that ME in Rarámuri targets categories in specific areas of the layered structure of the verb with characteristic morpho-prosodic properties which make them difficult to parse and prone to be reanalyzed as part of the stem. Specifically, I argue that the opaque inner morphological markers generate a morphological constituent that requires further affixation.

\section{Rarámuri Verb Structure}

Rarámuri is an agglutinative, mostly suffixing Uto-Aztecan language spoken in the Mexican State of Chihuahua by about 75,000 speakers. ${ }^{4}$ Figure 1 shows the relative order of the suffixes of the Rarámuri verb. ${ }^{5}$ The "inner stem" is the input to suffixation, where lexicalized and unproductive or semi-productive processes take place.

\footnotetext{
Motion; N - Nominative; PARTC - Participle; PRES - Present; PST - Past; PST:1 - Past $1^{\text {st }}$ person; TR - Transitive; TR.PL - Transitive Pluractional.

${ }^{2}$ There are no case markers in this language and there is no pronominal form for third person.

${ }^{3}$ The characterization of Rarámuri's suffixes as derivational or inflectional was based on criteria such as generality/productivity, obligatoriness, recursivity and sensitivity to grammatical environment (Bybee 1985, Bickel \& Nichols 2001).

${ }^{4}$ This paper presents data of the Rarámuri dialect spoken in Choguita, municipality of Guachochi. The data were obtained through my field research in this community from 2003 to 2007.

${ }^{5}$ Ordering facts that partially motivate this organization are shown in the Appendix.
} 


\section{Multiple exponence of derivational morphology in Rarámuri (Tarahumara)}

Figure 1 - Suffix positions and categories expressed in the Rarámuri verb

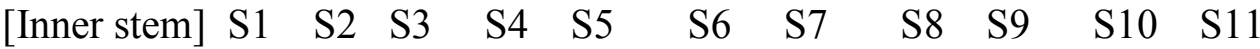
INCH TR APPl Mot CAUS APPL Desid Ev TAM TAM Subord.

This scheme does not imply a slot-and-filler, template-like structure. The verb has a layered, hierarchical structure that can be divided into stem levels, determined by morphophonological properties, such as back harmony and stress shifts. The morphological processes taking place closer to the root are tighter phonologically to the root than later morphological process. This is schematized in Figure 2.

Figure 2 - Rarámuri verbal stem levels and their morphophonology

\begin{tabular}{|c|c|c|c|c|c|}
\hline & & S1 S2 & S3 S4 S5 S6 & S7 S8 S9 S10 & S11 \\
\hline Stem levels & Inner Stem & $\begin{array}{l}\text { Derived } \\
\text { Stem }\end{array}$ & $\begin{array}{l}\text { Syntactic } \\
\text { Stem }\end{array}$ & Finite Verb & $\begin{array}{l}\text { Subord. } \\
\text { Verb }\end{array}$ \\
\hline \multirow{3}{*}{ 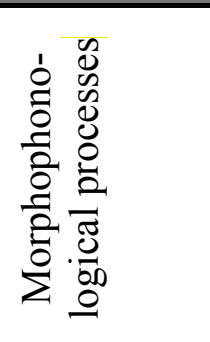 } & $\begin{array}{l}\rightleftarrows \\
\text { Compensatory } \\
\text { lengthening }\end{array}$ & & & & \\
\hline & \multicolumn{2}{|c|}{ 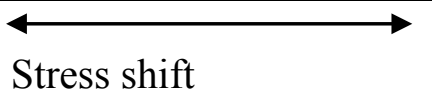 } & & & \\
\hline & \multicolumn{3}{|c|}{$\longleftrightarrow$ Back harmony } & & \\
\hline
\end{tabular}

Stress is assigned in either the first, second or third syllable, on either the root or on suffixes that are cohering prosodically with the stem (there is an initial three-syllable stress window (Caballero 2005)). The stress behavior of suffixes is schematized in Figure 3:

Figure 3 -Rarámuri verbal stem levels and stress behavior of suffixes

[[[[[Inner Stem] S1 S2 Derived] S3 S4 S5 S6 syntactic] S7 S8 $\quad$ S9 S10 Finite] S1 1 Sub.]

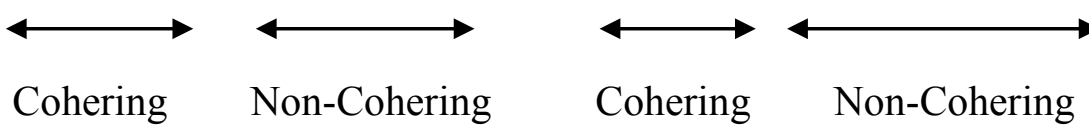

The syntactic stem (S3-S6) constitutes an intermediate zone: it is the domain of only one phonological process (back harmony), its suffixes are non-cohering, and causative $-t i$ and applicative $-k i$ (in S5 and S6) display ME, as it will be discussed in $\S 3.3$ and $\S 3.4$.

\section{Multiple Exponence in the Rarámuri Verb}

$\mathrm{ME}$ in this language is formally expressed in several ways: ${ }^{6}$

\footnotetext{
${ }^{6}$ Similar patterns are documented for a closely related language, Highland Guarijío (Miller 1996).
} 


\section{Gabriela Caballero}

a) Prefixation and stem consonant mutation to mark intensive aspect (\$3.1).

b) Applicative stems that redundantly take applicative suffixes (\$3.2).

c) Multiple suffixation of causative and applicative suffixes with no parallel semantic recursivity $(\S 3.3$ and $\S 3.4)$.

Though patterns (a) and (b) are not uncommon cross-linguistically, to my knowledge there are only a few documented cases of pattern (c) for derivational morphology. ${ }^{7}$

\subsection{Prefixation and Medial Consonant Mutation in the Intensive}

Rarámuri "intensives" (pluractionals) indicate in the verb a plural subject, or an action that occurs or is being performed by several agents or by the same agent several times (Lionnet 1968). Intensives, appearing frequently in text but of receding productivity, are marked through prefixation (a), consonant mutation (b), or marked through both prefixation and consonant mutation $(\mathrm{c}-\mathrm{d}){ }^{8}$

$\begin{array}{clll}\text { (3) a. } & \text { čóni } & \begin{array}{l}\text { Intensive } \\ \text { o-čóni }\end{array} & \text { 'to become black' } \\ \text { b. } & \text { kapórame } & \text { kabórame } & \text { 'to be round' } \\ \text { c. } & \text { kipá } & \text { i-kibá } & \text { 'to snow' } \\ \text { d. } & \text { bahí } & \text { a-pahí } & \text { 'to drink' }\end{array}$

The forms with both prefixation and consonant mutation do not have alternative forms with a single exponent for the intensive.

\subsection{Applicative Stems Adding Applicative Suffixes}

Another ME pattern involves applicative stems. There are unaccented and accented roots and stress-perturbing and stress-neutral suffixes in Rarámuri. Stressperturbing suffixes trigger stress shifts and vowel alternations with unaccented stems. Unaccented stems have a valence stem allomorphy system (schematized in Table 4): applicative stems are formed by replacing the final stem vowel with a stressed front vowel (e.g., (4c)).

\begin{tabular}{|c|c|c|c|}
\hline Intransitive & Transitive & Applicative & \\
\hline - & ori-/orá & orí & 'cut grains from cob' \\
\hline - & iči-/ičá & ičí & 'plant' \\
\hline noko/noká & - & noké & 'move' \\
\hline suwí & suwá & suwé & 'run out/finish up' \\
\hline
\end{tabular}

\footnotetext{
7 Similar cases are found in Bantu (e.g., causative doubling in Jita (Downing 2005), Kinande (Mutaka and Hyman 1990), and Bemba (Hyman 1994)).

${ }^{8}$ The prefix (originally $i$-) assimilates in color with the first stem vowel (Lionnet 1968).
} 
Multiple exponence of derivational morphology in Rarámuri (Tarahumara)

(4) a. nihé ba'arí iči -méa muní

1SGN TOMORROW PLANT -FUT.SG BEANS

'I will plant beans tomorrow'

b. nihé sunú ičá -ki rapáko

1SGN CORN PLANT -PST:1 YESTERDAY

'I planted corn yesterday'

$\begin{array}{lllllll}\text { c. nihé } & \text { ba'arí } & \text { ne } & \text { yé } & \text {-ra ičí } & \text {-ma } \\ & \text { 1SGN } & \text { TOMORROW } & \text { 1SGN } & \text { MOTHER-POSS PLANT.APPL-FUT.SG }\end{array}$

'I will plant for my mom tomorrow'

These applicative stems might add an applicative suffix in an apparently redundant fashion (e.g. (5b-6b)).

(5) a. nihé ba'arí ne yé -ra ičí 1SGN TOMORROW 1SGN MOTHER-POSS PLANT.APPL-FUT.SG

'I will plant for my mom tomorrow'

b. nihé ne yé -ra ičí -ki -ma 1SGN 1SGN MOTHER-POSS PLANT.APPL -APPL -FUT.SG

'I will plant for my mom'

(6) a. ma mi mi suwé -ri remé ALREADY $=1 \mathrm{SGN}$ 2SGA FINISH.UP.APPL-PST TORTILLAS

'I already finished (ate) up your tortillas'

b. ma $=$ ni mi suwé -ki -ri remé ALREADY $=1 \mathrm{SGN}$ 2SGA FINISH.UP.APPL -APPL -PST TORTILLAS

'I already finished (ate) up your tortillas'

There is free variation between the verbal forms that have one applicative marker (5a, 6a) and the forms with two applicative markers $(5 \mathrm{~b}, 6 \mathrm{~b})$.

\subsection{Multiple Affixation of Causative}

The Rarámuri causative suffix adds a causer argument to both intransitive and transitive verbs. The causative suffix has two allomorphs, $-t i(7 \mathrm{a})$ and $-r i(7 \mathrm{~b}){ }^{9}$ The distribution of the allomorphs is largely unpredictable, but following general rules of allophony in the language, the allomorph with the voiceless onset $(-t i)$ is used post-consonantally. In (7c) post-tonic vowel deletion yields an environment in which the onset of the causative is voiceless.

\footnotetext{
${ }^{9}$ All suffixes with a stop onset display this allomorphy.
} 


\section{Gabriela Caballero}

(7) a. ne mi napá -ti $\quad$-ma ta múchi 1SGN 2SGA HUG -CAUS -FUT.SG DEM BABY 'I will make you hug the baby'

b. ne mi pewá -ri -ma bahí -wa 1SGN 2SGA SMOKE-CAUS -FUT.SG DRINK -HAB.PASS -LOC 'I will make you smoke at the drinking party'

$\begin{array}{llllll}\text { c. } & \text { ti } & \text { michípiri tamí láan } & \text {-ti } & \text {-ki *lán-ri-ki } \\ \text { /ti } & \text { michípiri tamí láni } & \text {-ti } & -k i \\ \text { DEM } & \text { SPLINTER } & \text { 1SGA } & \text { BLEED } & \text {-CAUS } & \text {-PST } \\ \text { 'the splinter made me bleed' }\end{array}$

A very productive pattern of ME in Rarámuri involves repetition of the causative suffix, where post-tonic vowel deletion yields non-identical allomorphs of the causative suffix, as shown in (8). ${ }^{10}$

$$
\begin{aligned}
& \text { á }=\text { mi tamí mé } \quad \text {-r } \quad \text {-ti } \quad \text {-ma? } \\
& \text { AfF }=2 \mathrm{SGN} 1 \mathrm{SGA} \text { WIN -CAUS -CAUS -Fut.SG } \\
& \text { 'will you make me win?' }
\end{aligned}
$$

The possibility of having ME of the causative is conditioned by the position of stress and post-tonic vowel deletion. There are stems that have final or pre-final stem stress depending on tense/aspect morphemes or alternating freely. On these stems, non-final stem stress yields a form with one causative (9a), while final stem stress yields a form with ME (9b).

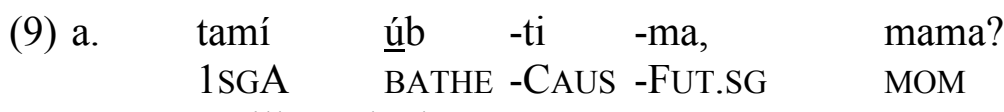

'Will you bathe me, mom?'

b. tamí ma ubá -r $1 \mathrm{SgN}$ ALREADY BATHE-CAus-CAus-PST 1SGN MOM-Poss 'my mom already bathed me'

The distribution of ME of causatives is consistent with this prosodic generalization: final-stress stems will optionally have ME of the causative (10-11). The forms with one causative freely alternate with forms with two causatives.

(10) a. ne mi mé -r -ma orá

1SGN 2SGA WIN -CAUS -FUT.SG EV

'I will make you win'

\footnotetext{
${ }^{10}$ Recall that the two allomorphs are also used with compositional semantics (cf. (1b))
} 
Multiple exponence of derivational morphology in Rarámuri (Tarahumara)

b. ne mi mé $\quad$-r $\quad$-ti $\quad$-ma orá 1SGN 2SGA WIN -CAUS -CAUS -Fut.SG Ev 'I will make you win'

(11) a. muhé ma tamí haré wási ko’í -ri 1SGN ALREADY 2SGA SOME COWS KILL -CAUS -PST 'You already made me kill some cows'

b. ne mi haré wási ko'í $\quad$-r $\quad$-ti 1SGN 2SGA SOME COWS KILL.PL -CAUS -CAUS-FUT.SG CER 'I will make you kill some cows'

Stems with non-final stress, on the other hand, where post-tonic vowel deletion targets the final vowel of the stem, never display double causative suffixation, as in the examples in (12).

$$
\begin{aligned}
& \text { nihé émi ték } \quad \text {-ti } \quad \text {-ma *ték-r-ti-ma } \\
& \text { /nihé émi téki -ti -ma/ } \\
& \text { 1SGN 2PLA BE.DRUNK.PL -CAUS -FUT.SG } \\
& \text { 'I will make you all drunk' } \\
& \text { b. nihé mi paník -ti -ma *paník-r-ti-ma } \\
& \text { /nihé mi paníki -ti -ma/ } \\
& \text { 1SGN 2SGA WASH.HANDS -CAUS -FUT.SG } \\
& \text { 'I will make you wash your hands' }
\end{aligned}
$$

\subsection{Multiple Suffixation of Applicative}

The applicative suffix - $k i$ adds a benefactive argument ('to do $\mathrm{X}$ for $\mathrm{Y}$ '), and, as the causative suffix, it can be doubled with no equivalent semantic compositionality (13-14). The forms with one and two applicatives are judged to be semantically equivalent.

(13) a. ne mi semé $-\mathbf{k i} \quad$-ma orá biré takí 1SGN 2SGA PLAY -APPL -FUT.SG EV ONE SONG 'I will play one song for you'

b. ne mi semé $-\mathbf{k i} \quad-\mathbf{k i} \quad$-ma orá biré takí 1SGN 2SGA PLAY -APPL -APPL -FUT.SG EV ONE SONG 'I will play one song for you'

$\begin{array}{llllllll}\text { (14) a. } & \text { ne } & \text { mi } & \text { wató } & \text {-n } & \text {-ki } & \text {-ma } & \text { úle } \\ & \text { 1SGN } & \text { 2SGA } & \text { STRETCH } & \text {-TR } & \text {-APPL } & \text {-FUt.SG } & \text { RUBBER }\end{array}$ 'I will stretch out the rubber for you' 


\section{Gabriela Caballero}
b. ne mi wató $-\mathrm{n}$-ki $-\mathbf{k i}$-ma úle $1 \mathrm{sgN} \quad 2 \mathrm{sgA}$ STRETCH -TR -APPL -APPL -FUT.SG RUBBER
'I will stretch out the rubber for you'

Unlike ME of causatives, ME of applicative $-k i$ is not prosodically conditioned, and is very restricted and subject to considerable speaker variation.

There are, however, other, less restricted patterns of ME involving applicatives in Rarámuri. Suffixes $-n i$ and $-s i$ introduce benefactive arguments, but are less general and productive than suffix $-k i$. Verbs taking suffixes $-n i(15)$ and $-s i$ (16) can add the more productive suffix $-k i$ :

$\begin{array}{lllllll}\text { (15) a. } & \text { ne } & \text { mi } & \text { sú } & \text {-n } & \text {-ma } & \text { sipúcha } \\ & 1 \mathrm{SGN} & 2 \mathrm{SGA} & \text { SEW } & \text {-APPL } & \text {-FUT.SG } & \text { SKIRT }\end{array}$ 'I will sew a skirt for you'

b. ne mi sú $\quad$-n $\quad$-ki $\quad$-ma $\quad$ sipúcha 1SGN 2SGA SEW -APPL -APPL -FUT.SG SKIRT 'I will sew a skirt for you'

(16) a. ma $\quad$ ni mi pá -si -ri pelota ALREADY=1SGN 2SGA THROW-APPL -PST BALL 'I already threw the ball at you'

b. ma $\quad$ ni mi pá $\mathbf{- s i} \quad-\mathbf{k i}$-ri pelota ALREADY=1SGN 2SGA THROW-APPL -APPL -PST BALL 'I already threw the ball at you'

The examples in (16-17) show that in these cases there is also free variation between the forms with one and two applicative suffixes.

\section{ME as Morphological Transparency}

There are, then, several patterns of ME in Rarámuri that involve derivational information (intensive, causative and applicative). What should be accounted for is the fact that $\mathrm{ME}$ is restricted to the inner stem and the syntactic stem:

Figure 4-Rarámuri verbal stem levels and the occurrence of $M E$

[Inner stem] S1 S2 Derived stem] S33 S4 $\underline{\text { S5 S6 }}$ syntactic stem] S7 S8 S9 S10 Finite verb] S11 Subord.] $\mathrm{ME}$ $\mathrm{ME}$

What these specific areas of the verb have in common is that the morphological markers that belong in these zones are difficult to parse. According to Hay \& Plag (2004), affixes have different degrees of decomposability or parsability in speech perception, and occupy a place along a processing complexity scale. On this account, affixes difficult to parse are less separable affixes with higher 


\section{Multiple exponence of derivational morphology in Rarámuri (Tarahumara)}

boundary strengths, either because they are less phonologically segmentable, less transparent, less frequent and/or less productive (2004:571).

The morphological markers exhibiting ME in Rarámuri are difficult to parse in two ways: they are either increasingly unproductive (intensive and applicative) or less phonologically segmentable due to a high degree of morphophonological fusion (causative). Thus, the overarching mechanism generating $\mathrm{ME}$ in the Rarámuri verb is morphological opacity: ME arises when a morphological marker is difficult to parse and a second round of marking is required for the sake of morphological transparency.

ME in the syntactic stem, a verbal zone with non-cohering suffixes, is prosodically conditioned. As shown in $\S 3.3, \mathrm{ME}$ of the causative suffix depends on stress assignment and post-tonic vowel deletion. Post-tonic vowel deletion targets the nucleus of the causative suffix, making this suffix less phonologically segmentable. Specifically, the inner copy of the causative is getting fused phonologically and reanalyzed as part of the stem; the outer copy is there for morphological transparency. This is shown schematically in Figure 5.

Figure 5 - Reanalysis of causative allomorph

Post-tonic V deletion: Reanalysis and further suffixation:

mé-ri-ma - mé-r-ma - mér-ti-ma

The first copy of the causative, reanalyzed as part of the stem, generates a Causative Stem, a morphological constituent that requires further suffixation.

Doubling of applicative suffix $-k i$, on the other hand, seems to arise through analogical extension with the causative. In this case analogical extension is plausible, given the morpho-syntactically relatedness of causative and applicative, and the adjacency of these suffixes in the layered structure of the verb.

Finally, the remaining cases of ME can also be thought of as arising from morphological opacity. In these cases, ME targets categories that are less parsable due to their decreasing productivity. The intensive pattern, which involves prefixation and consonant mutation, is archaic and has been argued to originate in a formerly productive stress pattern with voiceless/fortis onsets of stressed syllables (Lionnet 1972). ${ }^{11}$ The applicative patterns, however, are a more recent development: both the applicative stems with vowel alternations and the roots that take the less general applicative suffixes are re-interpreted as requiring the further affixation of the more productive and general applicative suffix $-k i$. There are no

\footnotetext{
${ }^{11}$ The reduplicated forms would have a plosive voicing pattern opposite to that of unreduplicated stems. The loss of the rhythmic pattern, plus leveling of the stress differences between unreduplicated and reduplicated stems, would have then rendered the voicing alternation opaque.
} 


\section{Gabriela Caballero}

cases of applicative stems that add the less general suffixes $-n i$ and $-s i{ }^{12}$ Only the more productive applicative $-k i$ can be attached to an applicative stem. ${ }^{13}$

Since forms displaying ME co-exist freely with forms with no ME, we might consider this phenomenon as a first step in a historical process that has been proposed as the source of ME in Skou (Donahue 1999). In Skou, a language of New Guinea, a series of sound changes (loss of voicing and other contrasts) led to consonant cluster simplifications. These changes affected agreement prefixes, leading to loss of contrast in a large number of verb forms in paradigms. "These factors would appear to be sufficient to bring about a second process of cliticization onto the verb in order to preserve contrastive verbal agreement" (Donohue 2003:493). Similar developments have been proposed for the ME patterns of Limbu, a Kiranti language (van Driem 1997, Anderson 2001).

\section{Some Possible Implications}

This case raises the more general issue of the status of derivational morphology for realizational models of morphology, which are founded on the assumption that inflection and derivation belong to different components of the grammar, and thus differ in their formal properties (the 'Split Morphology Hypothesis' (Matthews 1972, Anderson 1992). ME is commonly described for inflection (particularly agreement), but not for derivation. This paper shows that ME can be morphologically conditioned and not constrained to inflection, constituting a possible example of how inflectional and derivational morphology do not differ drastically as to their formal morphological properties.

\section{References}

Anderson, Stephen. 1992. A-morphous Morphology. Cambridge: Cambridge University Press.

Anderson, Stephen. 2001. On some issues in morpological exponence. In G. Booij \& J. Van Marle (eds.), Yearbook of Morphology 2000, 1-17. Dordrecht/Boston/London: Kluwer.

Bickel, Balthasar \& Johanna Nichols. 2001. Inflectional morphology. To appear in: T. Shopen [ed.] Language typology and syntactic description. Cambridge: Cambridge University Press.

Booij, Geert. 2000. Inflection and derivation. In Gert Booij, Christian Lehmann \& Joachim Mugdan (eds.), Morphology, 360-369. Berlin: Walter de Gruyter.

\footnotetext{
${ }^{12}$ In Guarijío, a closely related language, an applicative stem might co-occur with the applicative suffix -nie (cognate to Rarámuri applicative -ni): čuhč-é-nie-na (LOAD-APPL-APPL-PRES) 'to load (something) over a beast' (Miller 1996:162)

${ }^{13}$ In contrast with other dialects of Rarámuri (cf. Caballero 2003), the variant spoken in Choguita is also innovating the replacement of some causative suffixes exclusive to predicates of change of state with the more general causative suffix $-t i$.
} 


\section{Multiple exponence of derivational morphology in Rarámuri (Tarahumara)}

Bybee, Joan. 1985. Morphology: a study of the relation between meaning and form. Amsterdam: Benjamins.

Caballero, Gabriela. 2003. Valence and Transitivity Changing Operations in Raramuri. In L. Barragan and J. Haugen (eds.), MIT Working Papers on Endangered and Less Familiar Languages \#5 - Studies in Uto-Aztecan Linguistics. Cambridge: MIT.

Caballero, Gabriela. 2005. The Stress System of Central Rarámuri: Root Privilege, Prosodic Faithfulness and Markedness Reversals. Ms, University of California, Berkeley. ROA-706.

Donohue, Mark. 2003. Agreement in the Skou Language: a Historical Account. Oceanic Linguistics 42:2. 479-498.

Downing, Laura. 2005. 'Jita Causative Doubling Provides Optimal Paradigms'. In L. Downing, T.A. Hall \& R. Raffelstein, eds. Paradigms in Phonological Theory, 122-144. Oxford: Oxford University Press.

Hay, Jennifer \& Ingo Plag. 2004. What constrains possible suffix combinations? On the interaction of grammatical and processing restrictions in derivational morphology. Natural Language \& Linguistic Theory 22: 565-596.

Hyman, Larry. 1994. 'Conceptual issues in the comparative study of the Bantu verb stem'. In S. Mufwene \& L. Moshi (eds.), Topics in African Linguistics, 3-34. Amsterdam: Benjamins.

Lionnet, Andrés. 1968. "Los intensivos en tarahumar". Anales del Instituto Nacional de Antropología e Historia. 135-46.

Lionnet, Andres. 1972. Los elementos de la lengua tarahumara. Mexico: Universidad Nacional Autonoma de Mexico.

Matthews, Peter H. 1972. Inflectional morphology: a theoretical study based on aspects of Latin verb conjugation. Cambridge: Cambridge University Press.

Miller, Wick R. 1996. Guarijío: gramática, textos y vocabularios. Mexico: UNAM, Instituto de Investigaciones Antropológicas.

Mutaka, Ngessimo \& Larry Hyman. 1990. 'Syllables and morpheme integrity in Kinande reduplication'. Phonology 7: 73-119.

Peterson, David A. 1994. Multiple Exponence and Morphosyntactic Redundancy. In E. Duncan, D. Farkas \& P. Spaelti (eds.), Proceedings of the Twelfth West Coast Conference on Formal Linguistics.

Sells, Peter. 2004. Syntactic Information and its Morphological Expression. In L. Sadler and A. Spencer (eds.), Projecting Morphology. Stanford: CSLI Publications.

Stump, Gregory. 2001. Inflectional Morphology: A Theory of Paradigm Structure. Cambridge: Cambridge University Press.

van Driem, George. 1997. A new analysis of the Limbu verb. In D. Bradley (ed.), Tibeto-Burman languages of the Himalayas. Volume 14 of of Papers in Southeast Asian Linguistics, 157-173. Camberra: Pacific Linguistics. 


\section{Gabriela Caballero}

Gabriela Caballero

University of California, Berkeley

Department of Linguistics

1203 Dwinelle Hall

Berkeley, CA 94720-2650

gcaballe@berkeley.edu

\section{Appendix: Ordering facts of the Rarámuri verb}

INCH (S1) - TR.PL (S2)

nehé rata -bá -ča -ma ko'wá -ami

1SGN HEAT -INCH -TR.PL-FUT.SG EAT -PRTC

'I will heat up the food'

TR (S2) - APPL (S3)

ne mi moo -bú $-\mathbf{n i}-\mathrm{ma}$ ta towí trókači

1SGN 2SGA GO.UP -TR -APPL -FUT.SG DEM BOY TRUCK

'I will lift you the boy up into the truck'

APPL (S3)-Mot (S4)
nám -ta hu nápu ma tamí
HEAR -PARTC COP COMP ALREADY 1SGA
'It sounds like (they) are already hunting it for me'

APPL (S6) - DESID (S7)

ne mi biré wási mi'rí -ki -niri muhé omáwarachi

1SGN 2SGA ONE COW KILL -APPL -DESID 2GNN PARTY

'I want to kill one cow for you, for your party'

DESID (S7) - EV (S8)

ne ko mayé ma bahí -ni -čin -o

1SGN EMPH THINK ALREADY DRINK -DESID-EV -EV

'I think it sounds like they already want to drink (start the drinking party)' 